\title{
"Normales" y estigmatizados: los símbolos de la estigmatización social en Juan Rulfo
}

I. Introducción

"Nunca había sentido que fuera más lenta y violenta la vida" (Rulfo, 2013, p. 54), dice el narrador en el cuento "Talpa" de Juan Rulfo. El fenómeno de la estigmati-

Este trabajo es resultado parcial del proyecto extenso "La agenda pendiente: vulnerabilidad, estigmatización y nuevos actores sociales en obras esenciales de la literatura mexicana contemporánea".

Se estudian aquí siete formas de estigmatización social encontradas en la obra completa de Juan Rulfo y su representación estética a través de la red simbólica a partir de la teoría microsociológica de Erving Goffman (1922-1982). La metodología de Goffman, generada en los años cincuenta, es una plataforma que permite abordar las realidades sociales significadas

en el texto de modo tanto innovador como riguroso. La relectura microsocial

de la obra de Juan Rulfo abre nuevas posibilidades de interpretación de sus imperativos poéticos y de las interacciones sociales en ella representadas, lo que permite acercarse a los mecanismos de construcción social del otro y del cambio sociocultural.

Palabras clave: estigma social, representación simbólica, microsociología, Juan Rulfo.

- Profesora-Investigadora de la Facultad de Letras y Comunicación de la Universidad de Colima.

Ilgarcia@ucol.mx zación es uno de los más violentos, dolorosos y discriminatorios que puede sufrir un individuo en el desenvolvimiento de las interacciones en la vida social.

Este trabajo es resultado parcial del proyecto extenso "La agenda pendiente: vulnerabilidad, estigmatización y nuevos actores sociales en obras esenciales de la literatura mexicana contemporánea". El artículo tiene como propósito analizar cuáles estigmas sociales se despliegan en la obra de Juan Rulfo y mediante qué imágenes simbólico-estéticas se expresan. Se estudian siete formas de estigmatización que se han encontrado en la obra de Rulfo, y su representación estética a través de la red simbólica. Por lo que se refiere al marco teórico que fundamenta el análisis, este se centra en los planteamientos microsociológicos de Erving Goffman y se complementa en las conclusiones 
del trabajo con las reflexiones en torno a la identidad de Anthony Giddens y de Zigmunt Bauman; el marco metodológico que sustenta la determinación y análisis del imaginario simbólico se apoya básicamente en la mitocrítica del antropólogo Gilbert Durand.

Aunque las obras de Rulfo -El llano en llamas (1953) y Pedro Páramo (1955) - se centran en la expresión del problema del campo mexicano (el fracaso del reparto agrario; la ruina económica y la violencia que proyectaban la Revolución mexicana y la Guerra Cristera hacia 1926), así como en la aceleración de la migración -interna hacia las tres ciudades principales del país (Guadalajara, Ciudad de México y Monterrey) y externa hacia Estados Unidos- de la primera mitad del siglo XX, el talentoso escritor supo captar también otro importante aspecto de la cultura mexicana: la edificación de estigmas sociales que han dejado huella, o que incluso siguen vigentes en la interacción cotidiana de la sociedad mexicana.

Rulfo reúne en sí mismo, como ningún otro escritor mexicano, tres experiencias: primero, la vivencia profundamente enraizada y auténtica de la tierra; segundo, la pertenencia a una familia de hacendados "que todo lo perdió en la Revolución” (Poniatowska, 1986, p. 144), lo que le permitió, por una parte, tener acceso a la lectura y la cultura y, por otra, percibir el sentimiento de pérdida social; y por último, la experiencia del desplazamiento a los espacios urbanos, ya que formó parte del éxodo de las muchedumbres que se trasladaron en la primera mitad del siglo XX de las zonas rurales y la llamada "provincia" mexicana a la entonces emergente Ciudad de México, buscando las oportunidades que en el lugar de origen se desdibujaban o soñando las alturas que la seductora capital prometía. Ese amplio caleidoscopio vital le abrió la posibilidad de abordar problemáticas esenciales individuales y colectivas del México de su época, anticipando incluso tendencias que se desplegarían 
muchos años después. La exclusión se vincula irremediablemente con la violencia, y el México representado por Rulfo se tiende entre la marginación y la violencia: "La violencia rulfiana registra los grandes impulsos de la marginalidad" (Monsiváis, 2008, p. 249).

"Pedro Páramo es un cacique. Eso ni quien se lo quite [...] es un cacique de los que abundan todavía en nuestros países" (Rulfo, 2000), pero, con lo esencial que resulta este asunto, la pregunta que Rulfo se plantea en su narrativa va todavía mucho más allá:

Por ejemplo, ignoramos cómo se produce y cunde la pobreza; quién o qué la causa y por qué. Yo no me preguntaría por qué morimos, pongamos por caso; pero sí quisiera saber qué es lo que hace tan miserable nuestra vida. Usted dirá que ese planteamiento no aparece nunca en Pedro Páramo; pero yo le digo que sí, que allí está desde el principio y que toda la novela se reduce a esa sola y única pregunta: ¿dónde está la fuerza que causa nuestra miseria? Y hablo de miseria con todas sus implicaciones (Rulfo, 2000).

La empatía entre el discurso social y el literario hace particularmente significativo el diálogo entre la sociología y el análisis de los textos. Este diálogo tiene una sólida tradición que pasa por Mijaíl Bajtín, Georg Lukács, Lucien Goldmann, Julia Kristeva o Edmond Cros, entre muchos otros, pero la teoría microsociológica de Erving Goffman aparece como una propuesta que, generada en los cincuenta, alcanza al siglo XXI llena de vigencia y vitalidad para analizar las obras literarias desde una plataforma metodológica tan rigurosa como innovadora.

La pionera metodología de Goffman, centrada en las interacciones cara a cara, permite abordar las realidades sociales representadas en el texto a partir de las presencias individuales de la vida cotidiana y de los fenómenos de estigmatización que se gestan en ella. El paradigma 
microsocial conduce a valorar en la literatura esa cualidad que Carlos Fuentes subrayó siempre: su capacidad para ser "instrumento de diálogo en este sentido profundo [...] diálogo entre géneros, entre fuerzas sociales, entre lenguajes y entre tiempos históricos contiguos o alejados [...]" (Fuentes, 1990, p. 170). La mirada sociológica sobre la obra de Juan Rulfo y sobre los saberes literarios en general contribuye a la construcción de la ética social.

Leer la obra de Rulfo desde la perspectiva de la representación de formas de estigmatización social lleva a reflexionar sobre las causas y la naturaleza de esa miseria que tanto le preocupó y a enfrentar un problema social medular. Rulfo encarna a los personajes de sus obras en el despliegue de lo que Erving Goffman (1989) llama la presentación de la persona en la vida cotidiana. El sociólogo canadiense se orienta al análisis de la vida social en una doble dirección: desde las nociones de simulación, actuación y fachada, ${ }^{1}$ y desde la construcción y operación de los estigmas sociales. El presente trabajo se enfocará en la categoría de estigma que Goffman elabora en el marco de la perspectiva microsociológica, sustentándola a partir de las interacciones sociales, es decir, de las relaciones entre el "yo" y los "otros", metodología que es posible llevar al análisis de los personajes de Juan Rulfo, cuyas experiencias pueden proyectarse desde la intimidad individual e interpretarse en un sentido social.

Un estigma es un atributo desacreditador definido en términos de relaciones, ${ }^{2}$ como advirtió Goffman (1986, p. 13). Es una característica que hace diferente al individuo

I. "Un status, una posición, un lugar social no es algo material para ser poseído y luego exhibido; es una pauta de conducta apropiada, coherente, embellecida y bien articulada. Realizada con facilidad o torpeza, conciencia o no, engaño o buena fe, es sin embargo algo que debe ser representado y retratado, algo que debe ser llevado a efecto" (Goffman, 1989, p. 86).

2. Es decir, "un atributo que estigmatiza a un tipo de poseedor puede confirmar la normalidad de otro $y$, por consiguiente, no es honroso ni ignominioso en sí mismo" (Goffman, 1986, p. 13). 
y que atrae la desaprobación del entorno social. Se trata de un atributo que, no constituyendo una falta social, moral o que ha sido saldada, se juzga como una marca que vuelve al individuo inferior e indeseable: "Es un estigma, en especial cuando él produce en los demás, a modo de efecto, un descrédito amplio, a veces recibe también el nombre de defecto, falla o desventaja" (Goffman, 1986, p. 12).

Las incontenibles consecuencias de la estigmatización son la exclusión y la discriminación social:

Creemos, por definición, desde luego, que la persona que tiene un estigma no es totalmente humana. Valiéndonos de este supuesto practicamos diversos tipos de discriminación, mediante la cual reducimos en la práctica, aunque a menudo sin pensarlo, sus posibilidades de vida (Goffman, 1986, p. 15).

Los individuos de un grupo social construyen una teoría del estigma para racionalizar el ejercicio del poder y la violencia sobre otros, e inundan el discurso cotidiano con términos referidos al estigma tales como "inválido, bastardo y tarado" (Goffman, 1986, p. 15). Un hecho fundamental en la operativización del estigma es que los individuos estigmatizados comparten de algún modo las mismas creencias que los "normales". Se consideran individuos normales "aquellos que no se apartan negativamente de las expectativas particulares que están en discusión" (Goffman, 1986, p. 15). Normales y estigmatizados, al compartir el mismo referente y acervo de creencias, sin elaborarlas críticamente, participan en complicidad en la elaboración de las redes que llevan a la intolerancia, el rechazo, la violencia y la discriminación.

En el fenómeno de la estigmatización es fundamental la transmisión de la información social que proporciona el propio individuo a través de signos que se proyectan desde su propia persona. En este trabajo se coincide con la definición de Goffman (1986): son símbolos aquellos 
"signos portadores de información social [que] pueden ser accesibles en forma frecuente y regular, y buscados y recibidos rutinariamente" (p. 58). Esta noción de símbolo se complementa con la perspectiva mitocrítica de Gilbert Durand (1993), para quien, metodológicamente, podemos decir que "el símbolo es un caso límite del conocimiento indirecto" (p. 18), es decir, su aspecto concreto, su apariencia sensible, expresa un significado ausente, pleno de lecturas culturales. El símbolo es un tipo de signo caracterizado por inconclusión, ambigüedad, redundancia, estabilidad y memoria cultural, y por poseer un excedente de sentido que el sujeto que lo interpreta ha de completar, acercándose así a los significados culturales que indaga. ${ }^{3}$

\section{Los símbolos de los estigmas sociales en la obra de Juan Rulfo}

Algunos aspectos de la obra de Juan Rulfo que se abordan en este trabajo han sido analizados desde muchas perspectivas por otros críticos; sin embargo, ya que ninguna serie de símbolos puede comprenderse de modo aislado, "es posible integrarla dentro de un significado si uno la articula con respecto a toda la estructura de clasificaciones que se da en la cultura de que se trata" (Douglas, 1973, p. 9). En este caso, el eje de articulación de los símbolos estudiados es la estigmatización social.

La estigmatización se vuelca en la obra de Rulfo en imágenes simbólicas mediante las cuales el escritor captura su impacto en la vida cotidiana representada en El llano en llamas y Pedro Páramo. En este análisis se han distinguido

3. Para ampliar la noción de símbolo puede revisarse el siguiente trabajo: García Peña, L. (2012). "Nociones esenciales para el análisis de símbolos en los textos literarios". $452^{\circ} \mathrm{F}$. Revista electrónica de teoría de la literatura y literatura comparada, (6), I24-I38. Recuperado de: http://www.452f.com/pdf/numero06/ garcia/06_452f_garcia_indiv.pdf 
siete formas de estigmatización que se abordarán ahora. Lo primero que hay que señalar es que Rulfo advierte que en el tejido social existe el concepto de marca, de individuo "señalado", término que se debe a los griegos, y no para bien, puesto que ellos crearon la palabra "estigma" -"marca, señal, punto, tatuaje" (Gómez de Silva, 1989, p. 279) - para referirse a signos corporales que revelaban una diferencia negativa en la persona. Así, en Pedro Páramo se lee que Juan Preciado "Se rebulle sobre sí mismo como un condenado. Y tiene todas las trazas de un mal hombre" (Rulfo, 2005, p. 109), y en "El hombre", cuento en el que es sumamente importante que el autor haya manejado un nivel genérico porque esto le permite proyectar la representación del personaje a la noción universal de ser humano, narra:

Los pies del hombre se hundieron en la arena dejando una huella sin forma, como si fuera la pezuña de algún animal. [...] "Pies planos -dijo el que lo seguía-. Y un dedo de menos. Le falta el dedo gordo en el pie izquierdo. No abundan fulanos con estas señas. Así que será fácil” (Rulfo, 2013, p. 29).

Una vez planteada la idea de que Rulfo cree en los individuos "marcados", "estigmatizados", se puede analizar la primera clase de marca, aclarando que se ha decidido abordarlos en un sentido de lo más particular a lo más general, tratando de ir avanzando progresivamente hacia los estigmas que aparecen como más totalizantes y abarcadores de la persona en el contexto de su obra.

Se encuentra primeramente, de forma reiterada, el estigma del mal hijo o la mala hija. Mucho se ha hablado del mito del padre ausente en la obra de Rulfo, pero lo que se destaca ahora es la representación del hijo que es percibido por los padres como una decepción, un fracaso de las ilusiones que se habían puesto en él. Es importante advertir que 
"los malos hijos" representados por Rulfo muestran, desde la más temprana infancia, alguna marca física o de carácter.

En Pedro Páramo, en el propio cacique se observa este estigma que su padre Lucas le asigna:

"Es un inútil”, decía de él mi difunto patrón don Lucas. "Un flojo de marca". Yo le daba la razón. "Cuando me muera váyase buscando otro trabajo, Fulgor". "Sí, don Lucas". "Con decirle, Fulgor, que he intentado mandarlo al seminario para ver si al menos eso le da para comer y mantener a su madre cuando yo les falte; pero ni a eso se decide". "Usted no se merece eso, don Lucas". "No se cuenta con él para nada, ni para que me sirva de bordón servirá cuando yo esté viejo. Se me malogró, qué quiere usted, Fulgor". "Es una verdadera lástima, don Lucas" (Rulfo, 2005, p. 98).

De igual forma, las hijas frustran las esperanzas paternas: "Tu madre decía que cuando menos nos queda la caridad de Dios. Y tú la niegas, Susana. ¿Por qué me niegas a mí como tu padre? ¿Estás loca?” (Rulfo, 2005, p. 141). En El llano en llamas también se encuentran "malas hijas". En "En la madrugada", Margarita frustra, esta vez, las expectativas maternas: "Serían las once de la mañana cuando entró Margarita en el corral, buscando a Justo Brambila, llorando porque su madre le había dicho después de mucho sermonearla que era una prostituta” (Rulfo, 2013, p. 46). En el cuento "Es que somos muy pobres", las hermanas mayores, que "desde chiquillas ya eran rezongonas" (Rulfo, 2013, p. 26), son el contraejemplo de Tacha, la niña de 12 años, poniendo desde luego por ahora aparte la causa de la pobreza, la cual será tratada más adelante:

$Y$ tan luego que crecieron les dio por andar con hombres de lo peor, que les enseñaron cosas malas. Ellas aprendieron pronto y entendían muy bien los chiflidos, cuando las llamaban a altas horas de la noche. Después salían hasta de día. Iban cada rato por agua al río y a veces, 
cuando uno menos se lo esperaba, allí estaban en el corral, revolcándose en el suelo, todas encueradas y cada una con un hombre trepado encima.

Entonces mi papá las corrió a las dos. Primero les aguantó todo lo que pudo; pero más tarde ya no pudo aguantarlas más y les dio carrera para la calle. Ellas se fueron para Ayutla o no sé para dónde; pero andan de pirujas (p. 26).

En "La herencia de Matilde Arcángel”, Euremio hijo es estigmatizado desde pequeño por el padre como el causante de la muerte de la madre, al considerar que con su llanto asustó al caballo desbocado que la mató:

Lo colmado estaba en lo alto y garrudo de que lo había dotado la benevolencia de Dios Nuestro Señor al Euremio grande. En cambio al chico lo había hecho todo alrevesado, hasta se dice que de entendimiento. Y por si fuera poco el estar trabado de flaco, vivía si es que todavía vive, aplastado por el odio como por una piedra; y válido es decirlo, su desventura fue la de haber nacido. Quien más lo aborrecía era su padre, por más cierto mi compadre; porque yo le bauticé al muchacho [...] "Y yo para qué voy a quererlo. El de nada me sirve. La otra podía haberme dado más y todos los hijos que yo quisiera; pero éste no me dejó ni siquiera saborearla" (Rulfo, 20I3, pp. I45 y I50).

Desde entonces, el padre hace objeto al hijo de su resentimiento y su exclusión:

Euremio chico creció a pesar de todo, apoyado en la piedad de unas cuantas almas; casi por el puro aliento que trajo desde al nacer. Todos los días amanecía aplastado por el padre que lo consideraba un cobarde y un asesino, y si no quiso matarlo, al menos procuró que muriera de hambre para olvidarse de su existencia. Pero vivió (p. 150).

Los ejemplos se multiplican en la obra de Rulfo (2013). En "No oyes ladrar los perros", el padre señala que no le debe al hijo "más que puras dificultades, puras mortificaciones, 
puras vergüenzas” (p. 132). Este hijo, Ignacio, también presenta marcas de nacimiento:

Me acuerdo cuando naciste. Así eras entonces. Despertabas con hambre y comías para volver a dormirte. $Y$ tu madre te daba agua, porque ya te habías acabado la leche de ella. No tenías llenadero. Y eras muy rabioso. Nunca pensé que con el tiempo se te fuera a subir aquella rabia a la cabeza... Pero así fue (p. 133).

Y después de una larga serie de recriminaciones del padre hacia el hijo, el cuento cierra con la reconvención definitiva: “-¿Y tú no los oías, Ignacio? -dijo-. No me ayudaste ni siquiera con esta esperanza" (p. 134).

Se menciona también el caso del hijo migrante de "Paso del Norte" que pidiendo ayuda al padre en busca de mejor suerte para su propia familia, recibe esta respuesta:

-Ésos son rumores. Trabajando se come y comiendo se vive. Apréndete mi sabiduría. Yo estoy viejo y ni me quejo. De muchacho ya ni se diga; tenía hasta pa conseguir mujeres de a rato. El trabajo da pa todo y contimás pa las urgencias del cuerpo. Lo que pasa es que eres tonto. Y no me digas que eso yo te lo enseñé (Rulfo, 2013, p. I19).

Antes de dejar el estigma del mal hijo es posible volver a Pedro Páramo para mencionar el caso de Abundio Martínez, que resulta especialmente relevante porque este personaje, que también es hijo ilegítimo del cacique, es el arriero que al principio de la obra guía a Juan Preciado en su camino a Comala, y que vuelve a aparecer al final de la novela, ya que es el asesino de Pedro Páramo. Abundio Martínez da al texto su estructura circular y también cierra simbólicamente la obra con un mal hijo que llega al extremo de asesinar al padre.

La violencia engendra violencia. Los padres y las madres encuentran en los hijos y las hijas a los grandes culpables de

\section{0}


sus desventuras y fracasos, y se convierten en los primeros gestores de su estigmatización. Estos "malos hijos", hijos estigmatizados, son víctimas prácticamente desde su nacimiento de abandono, indiferencia, maltrato o humillación, y con el paso del tiempo sus vidas se encuentran hundidas en la locura y la violencia, hasta generarse "un rencor vivo" (Rulfo, 2005, p. 68) desde donde algún día serán a su vez padres de la misma calidad que los suyos.

El estigma de los malos hijos lleva a observar la representación de una familia en la que las interacciones que privan son autoritarias y agresivas, apremiadas por la pobreza misma. Sin embargo, es muy importante destacar que Juan Rulfo sugiere la revisión de los papeles maternos. Por mencionar el ejemplo más claro, mientras Juan Preciado, en Pedro Páramo, va en busca del padre que lo abandona y olvida, es la madre la que se vincula al amor, a la transparencia y a la solidaridad con el hijo. Ante la pregunta sobre cuál sería una representación paradigmática del siglo XX, el historiador Eric Hobsbawm (2000) propuso la imagen de "una madre con sus hijos" (p. 212). Es posible creer que las madres solas se insinúan en la obra de Rulfo como uno de los más importantes nuevos actores sociales de la contemporaneidad.

La segunda representación de estigma que es destacable es la que se refiere a la locura. La locura es el símbolo de la diferencia, de la marca, del comportamiento que se aparta de la normalidad de acuerdo con las expectativas de la interacción social. Este estigma se muestra en El llano en llamas en "Macario": "Dicen en la calle que yo estoy loco porque jamás se me acaba el hambre. Mi madrina ha oído que eso dicen. Yo no lo he oído. Mi madrina no me deja salir solo a la calle" (Rulfo, 2013, p. 62). También en Pedro Páramo, en donde la locura se manifiesta en Miguel: "Si se lo dijera a los demás de Comala dirían que estoy loco, como siempre 
han dicho que lo estoy" (Rulfo, 2005, p. 84), y en Susana a quien el padre le pregunta: “Estás loca?” (p. 141):

- ¿No lo sabías?

-iEstás loca?

-Claro que sí, Bartolomé. ¿No lo sabías? (p. 14I).

Susana "se vuelve loca" desde el día en el que su padre la hace bajar a la profundidad de la tierra en busca de oro y dinero; sin embargo, lo que ella encuentra es la presencia de la muerte, como señala el siguiente fragmento:

-Más abajo, Susana. Más abajo. Dime si ves algo.

Y cuando encontró el apoyo allí permaneció, callada, porque se enmudeció de miedo. La lámpara circulaba y la luz pasaba de largo junto a ella. Y el grito de allá arriba la estremecía:

-¡Dame lo que está allí, Susana!

Y ella agarró la calavera entre sus manos y cuando la luz le dio de lleno la soltó.

-Es una calavera de muerto -dijo.

-Debes encontrar algo más junto a ella. Dame todo lo que encuentres. El cadáver se deshizo en canillas; la quijada se desprendió como si fuera de azúcar. Le fue dando pedazo a pedazo hasta que llegó a los dedos de los pies y le entregó coyuntura tras coyuntura. Y la calavera primero; aquella bola redonda que se deshizo entre sus manos.

-Busca algo más, Susana. Dinero. Ruedas redondas de oro. Búscalas, Susana (p. 147).

Susana entonces enloquece de miedo, del mismo miedo intenso que, por cierto, mata a Juan Preciado: "Entonces ella no supo de ella, sino muchos días después entre el hielo, entre las miradas llenas de hielo de su padre" (p. 148). Juan Rulfo subrayó esta característica de alienación del personaje: "Ese Fulano que se casó con ella no existió nunca. Son locuras, son fantasías. Nunca conoció el mar, nunca 
se casó con nadie, siempre vivió con su padre" (González Boixo, 2005, p. 250). La imagen de la locura de Susana es fundamental porque de ahí deriva gran parte de la historia:

Aun así, es dable reconstruir un orden que, sin ser exactamente cronológico, remite a la escena originaria en el libro, que sería la fuente de la tragedia total: el momento en que Susana San Juan, obligada por su padre, desciende a una tumba en busca de oro, como la única manera de capitalizarse. Susana enloquece después de que ha llevado simbólicamente la muerte a la superficie de la tierra -no da a su padre "ruedas redondas de oro", sino una "calavera de muerto"-, de modo que el cacique mismo es culpable de la locura y muerte de Susana, causa a su vez de la extinción de Comala, en virtud de que el pueblo, sin darse cuenta, celebra la muerte de la mujer y Pedro Páramo jura vengarse por semejante ofensa (Vital, 1998, p. 47).

El estigma de la locura muestra cómo las estrategias que construyen al sujeto a partir de la normalización, como advirtió Michael Foucault, confinan al individuo estigmatizado y lo controlan, reforzando los mecanismos de poder y exclusión. La locura es finalmente una configuración social que estigmatiza, controla y margina. Juan Rulfo logra representar los sutiles mecanismos de vigilancia y castigo a través de los cuales el sujeto social es construido por las relaciones de poder de las cuales toda la sociedad participa. Los "normales" en la teoría de Erving Goffman, que estigmatizan a quienes no lo son en sus términos, equivalen en Foucault (1998) a "la mirada que está por doquier en movimiento. Un cuerpo de milicia considerable, mandado por buenos oficiales y gentes de bien" (p. 199). El espacio ficcionalizado en la obra de Rulfo refiere a aquel descrito por Foucault (1998) como "Espacio recortado, inmóvil, petrificado. Cada cual está pegado a su puesto. Y si se mueve, le va en ello la vida, contagio o castigo" (p. 199); la locura 
es el símbolo del que se aparta de la normalización en las interacciones sociales.

En un sentido más amplio que la locura como ausencia de salud mental, en la obra de Juan Rulfo aparece la enfermedad como el tercer estigma, que bajo muchas y diversas formas es un proceso que se desvincula de los procesos naturales de la vida y emerge siempre como una marca. La enfermedad es el vehículo que expresa simbólicamente las carencias y defectos del individuo. Está el caso de la mujer de Abundio, el hijo asesino de Pedro Páramo, de la que se dice: “[...] y no sé cuántos males tenía” (Rulfo, 2005, p. 176): "Pensó en su mujer, que estaba tendida en el catre, solita, allá en el patio de su casa, adonde él la había sacado para que se serenara y no se apestara pronto" (p. 176); y el caso del propio cacique que, mucho tiempo antes del día en que es acuchillado por Abundio, se va muriendo poco a poco, inmovilizándose:

Allá atrás, Pedro Páramo, sentado en su equipal, miró el cortejo que se iba hacia el pueblo. Sintió que su mano izquierda, al querer levantarse, caía muerta sobre sus rodillas; pero no hizo caso de eso. Estaba acostumbrado a ver morir cada día alguno de sus pedazos (p. 177).

En El llano en llamas, Remigio Torrico es el tuerto de "La cuesta de las comadres" cuyo "ojo negro y medio cerrado que le quedaba parecía acercar tanto las cosas, que casi las traía junto a sus manos" (Rulfo, 2013, p. 16); y el migrante de "Paso del Norte" es totalmente vulnerable con el brazo roto:

Y así se estuvo dale y dale hasta que me zarandió de los cabellos y yo ni metí las manos, por eso del codo dañado que ni defenderme pude. "Le dije: -No me pegue, que estoy manco.

"Y hasta entonces le paró a los golpes (Rulfo, 2013, p. 122). 
“Normales” y estigmatizados: los símbolos de la estigmatización social en Juan Rulfo

Está también el caso del hermano enfermo desahuciado de "Talpa":

La idea de ir a Talpa salió de mi hermano Tanilo. A él se le ocurrió primero que a nadie. Desde hacía años que estaba pidiendo que lo llevaran. Desde hacía años. Desde aquel día en que amaneció con unas ampollas moradas repartidas en los brazos y las piernas. Cuando después las ampollas se le convirtieron en llagas por donde no salía nada de sangre y sí una cosa amarilla como goma de copal que destilaba agua espesa. Desde entonces me acuerdo muy bien que nos dijo cuánto miedo sentía de no tener ya remedio. Para eso quería ir a ver a la Virgen de Talpa [...] Ya allí, frente a Ella, se acabarían sus males; nada le dolería ni le volvería a doler más. Eso pensaba él (Rulfo, 20I3, p. 50).

Y también del "hijo ingrato", Ignacio, en "No oyes ladrar los perros": "Te llevaré a Tonaya a como dé lugar. Allí encontraré quien te cuide. Dicen que allí hay un doctor. Yo te llevaré con él" (Rulfo, 2013, p. 131).

En los estigmatizados por enfermedad en la obra de Juan Rulfo se muestra lo que bien señala el historiador barcelonés de la cultura occidental, Lluís Duch, la "salud y enfermedad son traducciones simbólicas de lo que, aquí y ahora, somos o creemos ser" (Solares y Lavaniegos, 2008, p. 152):

La enfermedad es caos, disfunción, somatización de nuestras irreconciliaciones profundas; la salud, en cambio, es un proceso, siempre precario, de cosmización, un reencuentro del rumbo a pesar del dato innegable e insuprimible que es nuestra congénita finitud (p. I52).

La crítica ha señalado reiteradamente que un eje esencial del mundo rulfiano es la religiosidad. Carlos Monsiváis (2008) señala el carácter específico que toma esa característica en la obra del maestro: "El sustrato unificador es, sí, el pecado, pero el pecado no está en las acciones de los personajes, sino en los actos de sus padres y abuelos que 
los endeudan con la eternidad y los obligan a merecer esta triste suerte que los angustia" (p. 253). El pecador, el culpable, es el siguiente estigma que se aborda. El estigma por culpa se extiende por toda la obra. Por ejemplo, Susana pregunta a Justina:

- ¿Verdad que la noche está llena de pecados, Justina?

-Sí, Susana.

- ¿Y es verdad?

-Debe serlo, Susana.

- ¿Y qué crees que es la vida, Justina, sino un pecado? ¿No oyes? ¿No oyes cómo rechina la tierra? (Rulfo, 2005, p. 164).

En El llano en llamas, el estigma del pecador se muestra en el padre de Justino en "Diles que no me maten", que pasa toda una vida escondido "de haberse pasado su mejor tiempo tirando de un lado para otro arrastrado por los sobresaltos y cuando su cuerpo había acabado por ser un puro pellejo correoso curtido por los malos días en que tuvo que andar escondiéndose de todos" (Rulfo, 2013, p. 92). También en "El hombre", que con su fuerza simbólica generalizadora parece incluir a todos los individuos, potencialmente, en el estigma del perseguido por la culpa:

"No debí haberme salido de la vereda -pensó el hombre-. Por allá ya hubiera llegado. Pero es peligroso caminar por donde todos caminan, sobre todo llevando este peso que yo llevo. Este peso se ha de ver por cualquier ojo que me mire; se ha de ver como si fuera una hinchazón rara. Yo así lo siento. Cuando sentí que me había cortado un dedo, la gente lo vio y yo no, hasta después. Así ahora, aunque no quiera, tengo que tener alguna señal. Así lo siento, por el peso, o tal vez el esfuerzo me cansó" (Rulfo, 20I3, p. 32). 
El estigma por la culpa conduce a la sensación de contaminación e impureza en el individuo. Mary Douglas (1973) recoge la observación que Paul Ricoeur enuncia en Finitud y culpabilidad: la impureza es una representación sumergida en un miedo específico mediante la cual se ingresa al reino del terror. El estigma del pecador es sumamente importante porque en él puede advertirse una característica fundamental del estigmatizado según Erving Goffman, que es el sentimiento de vergüenza que llega incluso a la autoaversión.

Un rasgo básico que caracteriza la percepción del individuo estigmatizado se refiere a la condición de aceptación y autoaceptación que queda cancelada en medio de una intensa sensación de incertidumbre que se filtra en todas las interacciones sociales. La estigmatización desata el sentimiento de vergüenza y autoaversión que lleva al individuo a autopercibirse como impuro: "Es probable que la presencia inmediata de los normales refuerce esta disociación entre las autodemandas y el yo, pero, de hecho, el individuo también puede llegar a odiarse y denigrarse a sí mismo cuando está solo frente a un espejo" (Goffman, 1986, p. 18):

Luego están nuestros pecados de por medio. Ninguno de los que todavía vivimos está en gracia de Dios. Nadie podrá alzar sus ojos al Cielo sin sentirlos sucios de vergüenza. $Y$ la vergüenza no cura. Al menos eso me dijo el obispo que pasó por aquí hace algún tiempo dando confirmaciones. Yo me le puse enfrente y le confesé todo:

"-Eso no se perdona -me dijo.

“-Estoy avergonzada (Rulfo, 2005, p. III).

En Pedro Páramo, Eduviges también está marcada con el sello de la culpa. Juan Preciado la describe:

Su cara se transparentaba como si no tuviera sangre, y sus manos estaban marchitas; marchitas y apretadas de arrugas. No se le veían los ojos. Llevaba un vestido blanco muy antiguo, recargado de holanes, y del 
cuello, enhilada en un cordón, le colgaba una María Santísima del Refugio con un letrero que decía: "Refugio de pecadores" (Rulfo, 2005, p. 79).

El letrero es la marca de la culpa, del pecado. Páginas más adelante, el lector se entera de las culpas que se le atribuyen: por el padre Rentería se sabe que se suicidó y por su hermana María Dyada que tuvo vínculos con varios hombres. Su suicidio aparece como expresión máxima de la autoaversión:

“-Pero ella se suicidó. Obró contra la mano de Dios.

“-No le quedaba otro camino. Se resolvió a eso también por bondad.

“-Falló a última hora -eso es lo que le dije-. En el último momento.

¡Tantos bienes acumulados para su salvación, y perderlos así de pronto!

“-Pero si no los perdió. Murió con muchos dolores. Y el dolor... Usted nos ha dicho algo acerca del dolor que ya no recuerdo. Ella se fue por ese dolor. Murió retorcida por la sangre que la ahogaba. Todavía veo sus muecas, y sus muecas eran los más tristes gestos que ha hecho un ser humano (p. 91).

De acuerdo con Mary Douglas (1973), una persona marginal que no encuentra lugar en el sistema social despierta en el entorno la sensación de peligro que la coloca fuera de las interacciones sociales ordinarias. El estigmatizado por la culpa se da cuenta de que despierta un sentimiento de impureza y peligrosidad en el entorno social; para Goffman, la vergüenza se origina cuando el individuo percibe uno de sus atributos como una cualidad impura.

En Pedro Páramo, la presencia del estigma del pecador destaca también en la hermana de la pareja incestuosa. El pecado es una marca que el personaje tiene la certeza de mostrar en su cuerpo:

Él no quiere creerlo, pero ¿verdad que estoy para dar miedo? -y se acercó a donde le daba el sol-. ¡Míreme la cara! 
Era una cara común y corriente.

-¿Qué es lo que quiere que le mire?

- ¿No me ve el pecado? ¿No ve esas manchas moradas como de jiote que me llenan de arriba abajo? Y eso es sólo por fuera; por dentro estoy hecha un mar de lodo (Rulfo, 2005, p. III).

Y es también visible en Natalia, la esposa de Tanilo Santos, en "Talpa", que lo traiciona con su hermano:

Yo sé ahora que Natalia está arrepentida de lo que pasó. Y yo también lo estoy; pero eso no nos salvará del remordimiento ni nos dará ninguna paz ya nunca [...] Pero ahora que está muerto la cosa se ve de otro modo. Ahora Natalia llora por él, tal vez para que él vea, desde donde está, todo el gran remordimiento que lleva encima de su alma (Rulfo, 20I3, pp. 5I-53).

Es importante notar entonces que la representación de la culpa o el pecado se desplaza en la obra de Juan Rulfo al estigma del incesto, lo cual puede verse en tres casos: la pareja incestuosa que aparece en Pedro Páramo y que existe en las alucinaciones de Juan Preciado: "No es mi marido. Es mi hermano; aunque él no quiere que se sepa" (Rulfo, 2005, p. 110), y que también muestra su condición fatal: "la vida nos había juntado, acorralándonos y puesto uno junto al otro" (p. 111); la esposa y el hermano de Tanilo Santos en "Talpa": "Y de eso nos agarramos Natalia y yo para llevarlo. Yo tenía que acompañar a Tanilo porque era mi hermano. Natalia tendría que ir también, de todos modos, porque era su mujer" (Rulfo, 2013, p. 51); y la relación entre Justo Brambila y su sobrina en el cuento "En la madrugada":

Justo Brambila dejó a su sobrina Margarita sobre la cama, cuidando de no hacer ruido. En la pieza contigua dormía su hermana, tullida desde hacía dos años, inmóvil, con su cuerpo hecho de trapo; pero siempre despierta. Solamente tenía un rato de sueño, al amanecer; entonces se 
dormía como si se entregara a la muerte [...] "Si el señor cura autorizara esto, yo me casaría con ella; pero estoy seguro de que armará un escándalo si se lo pido. Dirá que es un incesto y nos excomulgará a los dos. Más vale dejar las cosas en secreto" (Rulfo, 2013, p. 45).

A través del estigma del incesto se cuestiona simbólicamente, desde lo más esencial, la descomposición de la formación social, ya que la integridad de toda la estructura social puede ponerse en tela de juicio cuando se quebrantan las reglas del incesto: "entre los universales culturales más significativos están la exogamia y el tabú de incesto" (Kottak, 1999, p. 42).

Se habla ahora del estigma del migrante, que se conecta directamente con el más poderoso de los estigmas en la obra de Juan Rulfo, según se manifiesta en este trabajo, que es el de la pobreza en general y la del campo mexicano, su ruina, que empuja la necesidad de migrar. Juan Rulfo vivió la experiencia de la migración personalmente: se incorporó a la vida urbana desde 1927 cuando fue enviado a un internado en Guadalajara, el mismo año en que murió su madre; en 1933, viajó por primera vez a Ciudad de México para intentar estudiar en la Universidad Nacional Autónoma de México, y a partir de entonces vivió entre Guadalajara y la Ciudad de México, urbe en la que se estableció en 1962 cuando se incorporó al Instituto Nacional Indigenista y en la que falleció en 1986.

El estigma del migrante se sugiere en gran parte de la obra de Rulfo. Reiteradamente se dibujan los campos abandonados, en ruinas: "Todos escogen el mismo camino. Todos se van" (Rulfo, 2005, p. 177), se lee en Pedro Páramo. Aborda en su obra la relación que existe entre el abandono del campo y la migración a las ciudades de México o a Estados Unidos, y que Monsiváis (2009) resume: "Los años pasan y las causas del éxodo rural son las mismas: el desastre agrícola, la monotonía sin salidas, el caciquismo, la miseria 
que devora raíces, el alcoholismo, las vendettas familiares. (La novedad empieza con el narcotráfico)” (p. 23).

Como observan Meyer y Aguilar Camín (1997), la frontera norte atrajo a principios del siglo XX a una multitud de individuos de distinta ocupación y filiación ideológica, “y con eficacia tal que los 200 mil mexicanos que vivían en Estados Unidos en 1910 se habían cuadruplicado para 1930" (p. 87). La obra de Rulfo recoge la representación del migrante, narrando cómo la tierra "se llenó de 'adioses"' (Rulfo, 2005, p. 137):

-Allá, en el Paso del Norte, mientras nos encandilaban las linternas, cuando íbamos cruzando el río.

-iY por qué?

-Pos no lo supe, padre. ¿Se acuerda de Estanislado? Él fue el que me encampanó pa irnos pa allá. Me dijo cómo estaba el teje y maneje del asunto y nos fuimos primero a México y de allí al Paso. Y estábamos pasando el río cuando nos fusilaron con los máuseres (Rulfo, 2013, p. 121).

El último estigma del que se habla es para el caso de este trabajo, como ya se mencionó, el más poderoso de todos los representados: el de la pobreza. Los pobres son el grupo más señalado y marginado, el más severamente estigmatizado, excluido, devaluado e ignorado por los "normales" o estigmatizadores: para los pobres en la obra de Juan Rulfo, la tierra es "este valle de lágrimas" (Rulfo, 2005, p. 93). Los campesinos sufren toda suerte de injusticias y marginación: "El caso es que nuestras madres nos malparieron en un petate aunque éramos hijos de Pedro Páramo" (p. 68); son despojados de todo, de la tierra: "La tierra en ruinas estaba frente a él, vacía" (p. 178); se encuentran "tan escasos de todo, tan escasos..." (p. 110); endeudados, con las "carretas vacías" (p. 106); con las casas "con la mitad del techo caída" (p. 106); formando parte de una historia del campo mexi- 
cano que como Esteva (1980) resume, es "una historia de infinita violencia" (p. 12). Los pobres de Juan Rulfo, incluso el cura del pueblo en Pedro Páramo, están llenos "de polvo y de miseria" (Rulfo, 2005, p. 131); son tan pobres que ni siquiera tienen los medios para enterrar a sus muertos:

Abundio siguió avanzando, dando traspiés, agachando la cabeza y a veces caminando en cuatro patas. Sentía que la tierra se retorcía, le daba vueltas y luego se le soltaba; él corría para agarrarla, y cuando ya la tenía en sus manos se le volvía a ir; hasta que llegó frente a la figura de un señor sentado junto a una puerta. Entonces se detuvo:

-Denme una caridad para enterrar a mi mujer -dijo.

[...] Al no ver a nadie, repitió

-Vengo por una ayudita para enterrar a mi muerta (p. 175).

La pobreza, que estigmatiza y marca desde la niñez el rumbo de una vida marginal y deshumanizada, aparece en "Es que somos muy pobres":

Por eso le entra la mortificación a mi papá, ahora por la Tacha, que no quiere vaya a resultar como sus otras dos hermanas, al sentir que se quedó muy pobre viendo la falta de su vaca, viendo que ya no va a tener con qué entretenerse mientras le da por crecer y pueda casarse con un hombre bueno, que la pueda querer para siempre. $Y$ eso ahora va a estar difícil. Con la vaca era distinto, pues no hubiera faltado quien se hiciera el ánimo de casarse con ella, sólo por llevarse también aquella vaca tan bonita.

La única esperanza que nos queda es que el becerro esté todavía vivo. Ojalá no se le haya ocurrido pasar el río detrás de su madre. Porque si así fue, mi hermana Tacha está tantito así de retirado de hacerse piruja. Y mamá no quiere (Rulfo, 2013, p. 26).

El estigma de la pobreza cancela toda oportunidad en el presente y diluye toda posibilidad de futuro. Los campesinos se enfrentan a la carencia extrema que todo lo desintegra. 
"Entre otras características, la obra de Rulfo es una versión límite de estos condenados de la tierra" (Monsiváis, 2008, p. 244).

La obra de Rulfo llega a lo más hondo, al México rural, enraíza al lector en la realidad a través de una poesía que posee una energía sutil que a la vez es potente. La realidad ensombrecida, la tristeza de los desposeídos, la nostalgia de la pérdida forman un ángulo de la obra rulfiana. Él no quiso saber de falsas utopías, no endulzó las realidades, pero advirtió en su fotografía y en su narrativa los resquicios que dejan pasar la luz, las rendijas que filtran un nuevo aire. La esperanza, cuando se trata de Juan Rulfo, radica en la seducción de su fuerza apelativa, en su capacidad de atraer al lector, de resistir la múltiple relectura, de provocar la reflexión individual y social.

\section{Conclusiones}

Puede concluirse que la obra de Juan Rulfo muestra estigmas sociales presentes en la sociedad mexicana de la primera mitad del siglo XX. Es posible adelantar provisionalmente, aunque esto está sujeto a investigaciones posteriores sobre el tema, que algunos de los estigmas detectados permanecen hasta nuestros días, otros han desaparecido o se han generado nuevos. Sólo a manera de ejemplo, podemos mencionar que el estigma de la vejez no ocupa un lugar preponderante en la obra de Rulfo, como hoy sí lo hace en nuestra sociedad, y que las expectativas de vida han cambiado. La narrativa de Rulfo refiere, por ejemplo, que Fulgor Sedano, el administrador de la hacienda, con sus "54 años" (Rulfo, 2005, p. 94) ya es viejo: “-Pero cómo quiere usted que me quiera, si ya estoy viejo" (p. 97), y está "a pocos pasos de la muerte" (p. 100). No hay estigma por divorcio o por preferencia sexual en la obra de Rulfo, y el papel de los hijos y el valor simbólico de la enfermedad parecen cambiar en 
textos posteriores, mientras otros estigmas como la locura, la pobreza o el migrante sí parecen mantenerse. La revisión de la obra de Juan Rulfo, y de otras obras esenciales de la literatura mexicana, desde el paradigma microsocial de Erving Goffman, permitirá un mapeo de las interacciones sociales y los fenómenos de estigmatización y estereotipos en ella representados, y contribuirá a la comprensión de los mecanismos de cambio sociocultural.

Es posible creer que todos los estigmas encontrados en la obra de Juan Rulfo desembocan en dos grandes consecuencias sociales: la primera, el juicio ético que Juan Rulfo enuncia en su obra y que se refiere a que el valor de la vida humana queda en entredicho en nuestra sociedad. Se toman las palabras de Anthony Giddens (1995), que sitúa el fenómeno en términos universales: "La insignificancia personal, el sentimiento de que la vida no tiene nada valioso qué ofrecer, se ha convertido en un problema psíquico fundamental en las circunstancias de la modernidad tardía” (p. 18). La segunda, la condición de los seres humanos como deshechos, con estigmas que los reducen a nada, a residuos sociales. $\mathrm{Al}$ respecto, se toman las palabras de Zygmunt Bauman (2005), quien señala que los seres humanos residuales, excedentes, son una consecuencia inevitable de la modernización: "[...] un ineludible efecto secundario de la construcción del orden (cada orden asigna a ciertas partes de la población existente el papel de 'fuera de lugar', 'no aptas' o 'indeseables')” (p. 16). Un proyecto de largo alcance permitiría extraer conclusiones generales.

En la tarea de analizar textos, el rigor sociológico y la naturaleza estética de la literatura se concilian cuando se recurre a la brillante propuesta teórico-metodológica de Erving Goffman. La literatura se crece con el enfoque microsocial y la sociología se beneficia con el valioso espejo que constituyen las obras literarias en las que la sociedad se mira de cuerpo entero, especialmente en la magistral obra 
que Juan Rulfo, con su sensibilidad social y su perfección poética, ha dejado en la memoria cultural mexicana para siempre.

Fecha de recepción: 05 de febrero de 2015

Fecha de aceptación: 12 de mayo de 2015

Aguilar Camín, H. y Meyer, L. (1997). A la sombra de la Bibliografía Revolución mexicana. México: SEP.

Bauman, Z. (2005). Vidas desperdiciadas. La modernidad y sus parias. Barcelona: Paidós.

Douglas, M. (1973). Pureza y peligro. Un análisis de los conceptos de contaminación y tabú. Madrid: Siglo XXI.

Durand, G. (1993). De la mitocrítica al mitoanálisis. Barcelona: Anthropos.

Esteva, G. (1990). La batalla en el México rural. México: Siglo XXI Editores.

Foucault, M. (1998). Vigilar y castigar. Nacimiento de la prisión. México: Siglo XXI Editores.

Fuentes, C. (1990). Valiente mundo nuevo. Épica, utopía y mito en la novela hispanoamericana. México: FCE.

García Peña, L. (20I2). "Nociones esenciales para el análisis de símbolos en los textos literarios". $452^{\circ} \mathrm{F}$. Revista electrónica de teoría de la literatura y literatura comparada, (6), I24- 38. Recuperado de: http://www.452f.com/pdf/ numero06/garcia/06_452f_garcia_indiv.pdf

Giddens, A. (1995). Modernidad e identidad del yo: el yo y la sociedad en la época contemporánea. Barcelona: Ediciones Península.

Goffman, E. (1989). La presentación de la persona en la vida cotidiana. Buenos Aires: Amorrortu. (1986). Estigma. La identidad deteriorada. Buenos Aires: Amorrortu.

Gómez de Silva, G. (1989). Breve diccionario etimológico de la lengua española. México: FCE. 
Bibliografía

González Boixo, J. C. (2005). "Aclaraciones de Juan Rulfo a su novela Pedro Páramo", en Rulfo, J., Pedro Páramo (pp. 247-25I). Madrid: Cátedra.

Hobsbawm, E. (2000). Entrevista sobre el siglo XXI. Barcelona: Crítica.

Kottak, C. (1999). Antropología. Una exploración de la diversidad humana. Madrid: McGraw-Hill.

Monsiváis, C. (2009). Apocalipstick. México: Debate. (2008). Escribir por ejemplo. De los inventores de la tradición. México: FCE-SEP.

Poniatowska, E. (1986). ¡Ay vida, no me mereces! Carlos Fuentes. Rosario Castellanos. Juan Rulfo. La literatura de la onda. México: Planeta.

Rulfo, J. (20I3). El llano en llamas. México: Editorial RM y Fundación Juan Rulfo. (2005). Pedro Páramo. Madrid: Cátedra. (2000). "Pedro Páramo, cacique". Letras libres. Recuperado de: http://www.letraslibres.com/revista/ convivio/pedro-paramo-cacique

Solares, B. y Lavaniegos, M. (2008). "Entrevista con Lluís Duch. Del trayecto autobiográfico al proyecto antropológico”, en Duch, Ll.; Lavaniegos, M.; Capdevila, M. y Solares, B., Antropología simbólica y corporeidad cotidiana (Pp. I19-167). México: UNAM, Centro Regional de Investigaciones Multidisciplinarias. Recuperado de: http://www.crim.unam.mx/drupal/crimArchivos/ Colec_Dig/2008/Blanca_Solares_A/4_Entrevista_con_ Lluis_Duch.pdf

Vital, A. (1998). Juan Rulfo. México: Tercer MilenioConaculta. 